INTERNATIONAL JOURNAL OF ENVIRONMENT

Volume-2, Issue-1, Sep-Nov 2013

ISSN 2091-2854

Received:22 October

Revised:11 November

Accepted:12 November

\title{
AN ASSESSMENT OF PHYSICOCHEMICAL PROPERTIES, HEAVY METAL ENRICHMENT AND FUNGAL CHARACTERIZATION OF REFINED KEROSENE IMPACTED SOIL IN ANAND, GUJARAT, INDIA
}

\author{
Shamiyan R. Khan ${ }^{1}$, Nirmal Kumar J.I. ${ }^{2 *}$, Rita N. Kumar ${ }^{3}$ and Jignasha G. Patel ${ }^{4}$ \\ ${ }^{1,2,4}$ P.G. Department of Environmental Science and Technology, Institute of Science and \\ Technology for Advanced Studies and Research (ISTAR), VallabhVidya Nagar -388 120, \\ Gujarat, India \\ ${ }^{3}$ Department of Biological \& Environmental Sciences, N.V. Patel College of Pure \& \\ Applied Sciences, VallabhVidyanagar \\ *Corresponding author: istares2005@yahoo.com
}

\begin{abstract}
The present study was carried out to assess the physico-chemical properties, heavy metal enrichment and fungal isolation and characterization of the top soil samples collected in-situ from aged refined kerosene contaminated as well as uncontaminated garden soil sites in Anand, Gujarat, India. The total petroleum hydrocarbon (TPH) concentrations were 17,510 $\mathrm{mg} / \mathrm{kg}$ in kerosene contaminated soil against $142.65 \mathrm{mg} / \mathrm{kg}$ for uncontaminated soils. The contamination increased the soil organic carbon, nitrogen and clay to $2.95 \%, 0.612 \%, 36.22$ $\%$ as compared to $1.5 \%, 0.153 \%, 32.4 \%$ respectively in the uncontaminated soil. Increased concentration of heavy metals like Cobalt, Copper, Iron, Zinc and Lead against the uncontaminated soil was encountered. Ten native fungal speciesbelonging to a total of five genera include Aspergillus (A. terreus, A. versicolor, $A$. niger); Fusarium oxysporum; Penicilliumjanthinellum from the uncontaminated garden soil, whereas the contaminated soil included Aspergillus (A. terreus, A. versicolor, A. niger) Candida tropicalis,Cladosporiumbruhnei and Fusarium oxysporum, identified based on $18 \mathrm{~S}$ rRNA and the nucleotide sequences were submitted to the NCBI, GenBank database. The changes created by kerosene contamination resulted in variation in individual concentrations of physicochemical properties, soil conductivity, $\mathrm{pH}$ and soil fertility indices probably dwindle the growth of fungal strains causing a reduction in the fungal population in the kerosene contaminated soil.

Key Words: Refined Kerosene-contamination, Physicochemical analysis, Total Petroleum Hydrocarbons, Heavy Metals, Fungal growth and characterization 18S rRNA
\end{abstract}

\section{Introduction}

Contamination of the environment is frequently associated with hydrocarbon pollution because of the increasing global demand for petroleum hydrocarbons and its products. The growing demand for kerosene as the major energy source of domestic cooking and lighting has evidently led to disturbing cases of kerosene spillages. Kerosene is a complex mixture of hydrocarbons consisting of paraffins, cycloparaffins, aromatic and olefinic hydrocarbons with carbon numbers predominantly in the C9 to C16 range (Akpoveta, 
2011). The components of kerosene as a fraction of petroleum could pose serious environmental threats when they directly or indirectly enter into the environment because of their chemical nature. Since petroleum products contain some gaseous components, these fractions will volatilize when there is oil pollution leaving the non-volatile components as residues in and on the soil (Odu, 1977). It has been demonstrated that as a result of petroleum hydrocarbon intrusion during oil spillage, the physical and chemical nature of soils is altered (Minai-Tehrani and Herfatmanesh, 2007). The economic and environmental impacts of oil pollution on the soil are enormous causing serious damage to vegetation, soil fertility (Nwachukwu and Ugorji, 1995) and soil-borne microorganisms due to the toxic nature of the hydrocarbons. The toxicity varies depending on the type of oil and additives used during refining and also on the biota of spillage (Reddy, 2001).

Bioremediation of such soils involves intentional exposure of microbes to the contaminated site for clearance of the pollutants, the size of the microbal biomass is generally considered to be important. The microbial biomass itself represents a considerable pool of nutrients, which is continuously shunned into growth cycles of micro- macrophytes. Consequently, soils that maintain a high level of microbial biomass are capable of not only storing more nutrients, but also of cycling more nutrients through the system (Torstensson et. al., 1998). For the optimization of effective kerosene bioremediation processes it is essential to consider environmental and biological factors affecting the process. The environmental factors include availability of nutrients, $\mathrm{pH}$, soil texture and extent of kerosene contamination in the polluted soil, whereas the biological factors encompass the presence of bacterial, fungal or algal species which are responsible for bioremediation of kerosene in the contaminated soils (Bahuguna et al., 2011). The present study was carried out to study the effect of refined petroleum hydrocarbons on the physicochemical properties, heavy metal enrichment and fungal load of aged refined kerosene contaminated soil as compared with garden soil which would be further useful for standardization of in-situ bioremediation as well as biodegradation protocols.

\section{Materials and Method \\ Collection of Soil Samples}

Aged refined kerosene contaminated soil sample was collected from subsurface of twenty five years old kerosene vender site, located in VallabhVidyanagar, Anand, Gujarat, India whereas for control, uncontaminated garden soil was used. At both the sites, 10 top and sub-soil samples were collected randomly within a 0.5 meter quadrate and mixed into a composite sample representative of particular with a sterile spatula into a sterile polyethylene bag and taken to the laboratory immediately where stones in the samples were removed, the soils were homogenized through a $2 \mathrm{~mm}$ sieve and stored in the dark bottles till further analysis. All the parameters were carried out in triplicates and averages of three readings were considered.

\section{Determination of Physicochemical properties of Soil}

Soil samples were analysed forparticle- size by the international pipette method (Gee and Bauder 1986), bulk density with metal core sampler method (Blake and Harte 1986), porosity and moisture content according to Maiti (2003). The $\mathrm{pH}$, electric conductivity and salinity of the soil samples were determined in soil/ water $(1: 1)$ suspension by $\mathrm{pH}$ meter and conductivity meter (HACH, Sension 5, USA). Organic carbon was determined with titration method of Walkey and Black (1934). Total Nitrogen by Kjeldahl digestion (Gerhardt, Turbotherm, Germany.) and steam distillation method (Black 1965), sodium and potassium were determined using Flame photometer. Sulphate, phosphate, magnesium and calcium 
were estimated using procedures of Maiti (2003). The soil fertility indices considering the N, P, K, TOC and TOM was calculated (Osuji and Nwoye 2007).

\section{Heavy metals}

Heavy metals $(\mathrm{Cd}, \mathrm{Pb}, \mathrm{Cu}, \mathrm{Zn}, \mathrm{Co}$, and $\mathrm{Fe}$ ) were estimated by weighing $0.5 \mathrm{gm}$ of dried soil and digested with con. $\mathrm{HNO}_{3}, \mathrm{H}_{2} \mathrm{SO}_{4}$ and $\mathrm{H}_{2} \mathrm{O}_{2}(2: 6: 6)$ as prescribed by Nirmal Kumar et. al. (2008). The blanks were run in a set, and samples were analysed in Inductive Coupled Plasma Analyzer (ICPA) (Perkin- Elmer ICP Optima 3300 RL, U.S.A.) at Sophisticated Instrumentation Centre for Applied Research and Testing (SICART), VallabhVidya Nagar, Gujarat, India.. The concentrations of heavy metals were represented in $\mathrm{mg} / \mathrm{Kg}$. The enrichment factor $(\mathrm{EF})$ was calculated to derive the degree of soil contamination and heavy metal accumulations in soil at contaminated site with respect to uncontaminated (Kisku et. al., 2000).

$$
\text { Enrichment factor }(\mathrm{EF})=\frac{\text { Concentration of metals in soil at contaminated site }}{\text { Concentration of metals in soil at uncontaminated site }}
$$

\section{Determination of Total Petroleum Hydrocarbon (TPH) by Gas Chromatograph}

The soil samples were cleaned thoroughly mixed, $2 \mathrm{~g}$ of each soil sample was weighed into a clean extraction container. Then $10 \mathrm{ml}$ of extraction solvent (Chloroform, Dihloromethane, 1:1) was added into each sample, mixed thoroughly and allowed to settle. The mixtures were carefully filtered into a clean solvent extraction vessel, using filter paper fitted into buchner funnels. The extracts were concentrated to $2 \mathrm{ml}$ and then transferred for cleanup/separation. The concentrated aliphatic fractions were transferred into labelled vials with teflon caps for gas chromatograph (GC) analysis. The TPH was measured following USEPA Method 8015B for GC analysis with a FID detector and a HP-5 column at Sophisticated Instrumentation Centre for Applied Research and Testing (SICART). External calibration was conducted with the original kerosene fuel.

\section{Isolation and Identification of the indigenous fungal population.}

For isolation of the indigenous fungal population, one gram of each sorted soil sample was homogenously mixed with 1 drop $(0.1 \mathrm{ml})$ of Tween $80.1 .0 \mathrm{~g}$ of homogenized, $2 \mathrm{~mm}$ sieved soil sample was aseptically transferred, using a flame-sterilized steel spatula, into a sterile test tube containing $9.0 \mathrm{~mL}$ of sterile distilled water. This gave $10^{-1}$ dilution and subsequently, three-fold $\left(10^{-3}\right)$ serial solutions were prepared from the $10^{-1}$ dilution. $1 \mathrm{ml}$ of dilution was poured on Potato Dextrose Agar (PDA) plates and Soubraurd Dextrose Agar (SDA) plates, Streptomycin $(500 \mathrm{mg} / \mathrm{l})$ as antibiotic inhibit bacterial growth was added to the media after sterilization process (Harrigan and McCance, 1990). Thereafter, the plates were incubated at a temperature of $28-31^{\circ} \mathrm{C}$ for 48 hours or more depending on the rate of growth. To obtain pure cultures of the fungal isolates, fungal cultures were aseptically sub-cultured into fresh PDA and SDA plates and incubated until the fungus begins to sporulate followed by subsequent sub culturing to get pure cultures consisting of only one type of fungus isolates. A part of the pure culture was then aseptically transferred into sterile agar slants which had previously been prepared in sterile sugar tubes. The sugar tubes are then incubated till full growth of the fungus which served as stock cultures.

\section{Total Fungal population}

Both the contaminated and uncontaminated soils were checked for total fungal population using the colony forming unit (CFU) method (Lily et. al., 2009). For that $1 \mathrm{~g}$ of each soil sample was suspended into $10 \mathrm{ml}$ of sterile distilled water and serially diluted 
further up to $10^{-7}$ dilution aseptically. $0.1 \mathrm{ml}$ of each diluted soil suspension was poured onto Potato Dextrose agar plates using spread plate technique. Plates were incubated for 3-5 days at $30^{\circ} \mathrm{C}$. Fungal population growth was recorded as CFU per gram of soil.

\section{Identification of fungal isolates}

Fungal genera were identified according to morphological characters and classified according to taxonomical keys in many literatures (Nelson-Smith, 1973; Malloch, 1997). The inoculated plates were identified on the basis of culture (color and colonial appearance of fungal colony) and morphological characteristics. Species were identified by using DNA sequence method. A suitable mass of inoculum of fungal isolate was prepared with carefully removing the upper surface of the isolate without agar medium. The DNA extraction technique followed as per methods prescribed by Sambrook et al. (1989) and Nasrawi (2012). Genomic DNA was isolated from the fungal sample using Chromous fungal genomic DNA isolation kit following manufacturer's protocol (Chromous Biotech., Banglore, India). Mechanical lysis was enhanced using a Talboys High Throughput Homogenizer (Troemner, Thorofare, NJ, USA) at $1600 \mathrm{rpm}$ for 3 minutes. DNA extracts were assessed using a Nano-drop ND-1000 Spectrophotometer (Thermo Scientific, Wilmington, DE, USA). Fungal 18S rRNA genes were PCR amplified using 5'- GTAGTCATATGCTTGTCTC -3'and 5'GAAACCTTGTTACGACTT -3' primers. Reactions were performed in $100 \mu \mathrm{l}$ volumes containing $4 \mu \mathrm{ldNTPS}$, 400ng of each primer, 10X Taq DNA Polymerase Assay Buffer $10 \mu \mathrm{l}, 1$ $\mu \mathrm{l}$ of Taq DNA Polymerase enzyme, and $1 \mu \mathrm{l}$ template DNA. Thermo cycling conditions consisted of an initial de-naturation stage of $94^{\circ} \mathrm{C}$ for 5 minutes followed by 35 cycles of $94^{\circ} \mathrm{C}$ for 30 seconds, $55^{\circ} \mathrm{C}$ for 30 seconds, and $72^{\circ} \mathrm{C}$ for $1 \mathrm{~min}$, and a final stage of $72^{\circ} \mathrm{C}$ for 5 minutes. PCR products obtained were Gel eluted using Chromous Gel extraction kit and sent for sequencing on an ABI 3500 XL Genetic Analyzer (Applied Biosystems Inc., Foster City CA, USA). The basic local alignment search tool-BLAST was used to classify and identify closely related fungal sequences (Nasrawi, 2012).

\section{Nucleotide sequence accession numbers}

The nucleotide sequences reported in this paper have been submitted to the NCBI, GenBank database under the following accession numbers KC545846-KC545855, KC545856- KC545867 (Table 4).

\section{Results and Discussion}

\section{Physicochemical properties of refined kerosene contaminated and uncontaminated garden soil.}

In this study the total petroleum hydrocarbon (TPH) encountered in kerosene contaminated automobile site were $17,510 \mathrm{mg} / \mathrm{kg}$ and $142.65 \mathrm{mg} / \mathrm{kg}$ for uncontaminated garden soil. The high TPH is as a result of kerosene contamination. These concentrations of the TPH can make soil conditions unsatisfactory for plants and microbial growth (Dejong, 1980). This concentration of contamination will also increase the presence of toxic materials such as cresol, phenols, chlorine which might inhibit the growth of the hydrocarbon oxidizers (Ujowundu et. al., 2011).

As the texture of the soil plays a very important role in microbial and plant species establishment and development and also influences physical parameters of the soil. The kerosene contaminated soil had greater clay content $36.22 \%$, sand content $35.46 \%$ and silt content of $28.31 \%$, as compared to clay, sand and silt content of $32.4 \%, 42.4 \%$ and $25.2 \%$ respectively in the uncontaminated garden soil. Both the soils were classified as Clay Loam. The higher percentage of clay and silt in the kerosene contaminated soil suggests a reduction in soil aeration and porosity where porosity was encountered $64.47 \%$ as compared to $69.95 \%$ 
in the uncontaminated garden soil, which could affect crop productivity, yield and growth (Sztompka, 1999). The moisture content for contaminated and uncontaminated soils was $11.49 \%$ and $18.094 \%$ respectively. The low moisture contents of contaminated soils are due to the presence of hydrocarbons and PAHs which cause an increase in soil hydrophobicity and therefore leading to decrease in the moisture holding capacity of soil (Balks et al., 2002).

Osuji (2001) affirms high hydrocarbon levels affect both above-ground and subterranean flora and fauna, which are essential adjuncts in the biogeochemical cycle that affects availability of plant nutrients in Niger Delta. In general, plants require 16 essential elements for growth, 13 received from the soil, three of which $(\mathrm{N}, \mathrm{P}$, and $\mathrm{K})$ constitute the primary macro-nutrients. The soil fertility indices show the concentrations of extractable macronutrients $\mathrm{P}$ and $\mathrm{K}$ in the kerosene-impacted soil were significantly lower than in uncontaminated garden soil (Fig 1). This could be due to free hydrocarbons in the soil but more likely to utilize the nutrients by resident microflora. Osuji and Nwoye (2007) suggested that it is unlikely that the oil release is directly responsible for loss of macronutrients. Our results showed higher percentage value of nitrogen $6.12 \mathrm{mg} / \mathrm{kg}$ in kerosene contaminated soil and $1.53 \mathrm{mg} / \mathrm{kg}$ in uncontaminated soil which corroborated with the findings of Ujowundu et al. (2011), who studied the biochemical and physical characterization of diesel contaminated soil in southeastern Nigeria. The increase could be derived from the nitrogen content of the refined kerosene fuel (Slavica et al., 2003). High amount of organic carbon and organic matter in the contaminated soil samples could be due to kerosene fuel which is composed of hydrocarbon and PAHs (Atlas, 1981).

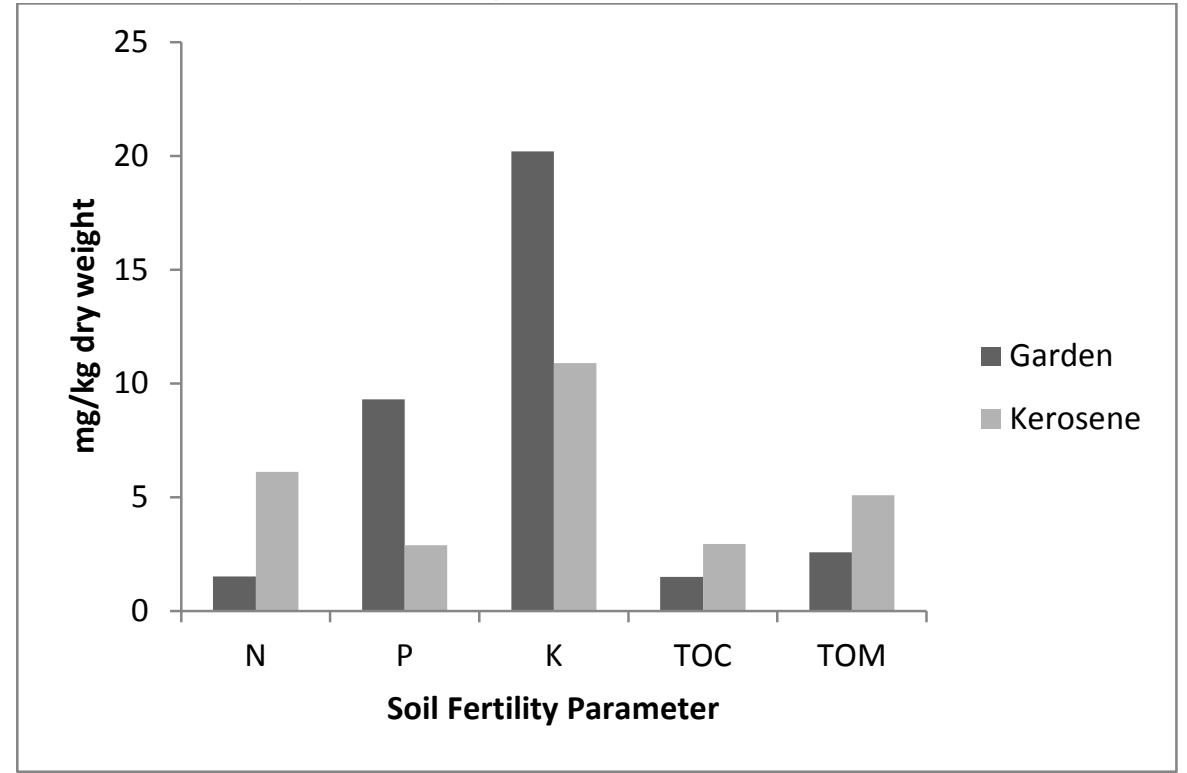

Figure 1. Soil fertility indices in refined kerosene contaminated and uncontaminated garden soils of Anand, Gujarat, India

The contamination may have resulted in the low $\mathrm{pH}$ value of 5.6 observed in the contaminated soil as compared to the 7.2 in the uncontaminated. The low $\mathrm{pH}$ may have caused a reduction in the fungal population growth in the contaminated soil. A study by Verstrateet. al. (1975) was conducted on optimal activity for microbial degradation at a $\mathrm{pH}$ of 7.4 and considerable inhibition at $\mathrm{pH} 4.5$ and 8.5. Similarly the high content of TPH may have also caused reduced fungal population growth observed in contaminated soil.

The results show a reduction in the nutrient content of the contaminated soil might have caused the lower conductivity value of $197 \mu \mathrm{S} / \mathrm{cm}$ in the kerosene contaminated soil when compared to $428 \mu \mathrm{S} / \mathrm{cm}$ in the uncontaminated (Table 1). It was found that the kerosene 
contaminant disturbed the soil structure and modified its physicochemical properties (Hawrot and Nowak, 2006). The reduction in the concentrations of sodium, calcium, potassium and magnesium which are suitable terminal electron acceptor would affect the indigenous microbial growth and metabolism (Ujowundu, 2011) (Table- 1).This could be the reason in the present investigation where the growth of fungal population declined.

Table 1: Physicochemical properties of refined kerosene contaminated and uncontaminated garden soils

\begin{tabular}{|l|c|c|}
\hline $\begin{array}{l}\text { Soil Physicochemical } \\
\text { Parameters }\end{array}$ & Garden(Uncontaminated) & Kerosene(Contaminated) \\
\hline \% Sand & 42.4 & 35.46 \\
\hline \% Silt & 25.2 & 28.31 \\
\hline \% Clay & 32.4 & 36.22 \\
\hline Texture Class & Clay Loam & Clay Loam \\
\hline Moisture content $(\%)$ & 18.094 & 11.49 \\
\hline Bulk density $(\mathrm{gm} / \mathrm{ml})$ & 0.68 & 1.10 \\
\hline Porosity $(\%)$ & 69.95 & 64.47 \\
\hline $\mathrm{pH}$ & 7.2 & 5.6 \\
\hline Electric Conductivity $(\mu \mathrm{s} / \mathrm{cm})$ & 428 & 197 \\
\hline Salinity $(\%)$ & 1.4 & 0.78 \\
\hline Na(mg/kg) & 90.34 & 54.87 \\
\hline Ca(mg/kg) & 33.7 & 12.96 \\
\hline Mg $(\mathrm{mg} / \mathrm{kg})$ & 141.28 & 70.89 \\
\hline Sulphate $(\mathrm{mg} / \mathrm{kg})$ & 879 & 1854 \\
\hline $\begin{array}{l}\text { Total Petroleum Hydrocarbons } \\
(\mathrm{mg} / \mathrm{kg})\end{array}$ & 142.65 & 17,510 \\
\hline
\end{tabular}

\section{Heavy metals}

The heavy metals cause potential threat to human health through drinking water when reach to ground water. Contaminated soil contained cadmium below the detectable limit. Iron $(\mathrm{Fe})$ was in elevated concentration in both contaminated and uncontaminated soils although iron occurs naturally in groundwater, and the higher concentration of iron has negative impact for human and animals (Table.2). Lead was found beyond the permissible limit of WHO and APHA in the kerosene contaminated soil. Lead $(\mathrm{Pb})$ found in contaminated soil during the course of experiment was $50.22 \mathrm{mg} / \mathrm{kg}$. Pb causes emotional changes, insomnia, neuromuscular changes, headaches etc., whereas $\mathrm{Cd}, \mathrm{Cu}, \mathrm{Zn}$ and $\mathrm{Pb}$ in the uncontaminated garden soils were found to be within the permissible limits of WHO and APHA. However, according to the Indian standards (Awashti, 2000; Sharma et al., 2006; Gupta et al., 2008) all the heavy metals in the kerosene contaminated soil were within in the prescribed limits.

There was a significant difference in enrichment factor (EF) values among the metals. Among six metals estimated, the maximal enrichment was found in case of Zinc ( $\mathrm{Zn}$ ), 4.42 and minimum to Cadmium as it was below detectable limits in both the soils. The values of EF were greater than 1, indicate higher availability and distribution of metals in contaminated soil, thereby increasing the metal accumulation in plants species grown on the contaminated soil (Kisku et al., 2000; Gupta et al., 2008). 
Table 2: Heavy metals content of refined kerosene contaminated and uncontaminated garden soils

\begin{tabular}{|l|c|c|c|c|c|}
\hline Heavy Metals & \multicolumn{2}{|c|}{ Permissible Limits } & Garden(Uncon \\
taminated) & $\begin{array}{c}\text { Kerosene(Conta } \\
\text { minated) }\end{array}$ & $\begin{array}{c}\text { Enrichment } \\
\text { factor }\end{array}$ \\
\hline Cadmium(mg/kg) & 0.3 & $3-6$ & BDL & BDL & 0 \\
\hline Cobalt $(\mathrm{mg} / \mathrm{kg})$ & N/A & N/A & 12.92 & 15.2 & 1.17 \\
\hline Copper(mg/kg) & 150 & $135-270$ & 79.08 & 115.8 & 1.46 \\
\hline Iron(mg/kg) & N/A & N/A & 1604.4 & 2457.4 & 1.53 \\
\hline Zinc $(\mathrm{mg} / \mathrm{kg})$ & 500 & $300-600$ & 79.08 & 349.64 & 4.42 \\
\hline Lead(mg/kg) & 40 & $250-500$ & BDL & 50.22 & N/A \\
\hline
\end{tabular}

BDL: Below Detectable Limits, N/A: Not Applicable

\section{Fungal Charaterization}

The fungal growth rate expressed in colony forming units were $2.7 \times 10^{6} \mathrm{cfu} / \mathrm{g}$ in the contaminated and $5.4 \times 10^{6} \mathrm{cfu} / \mathrm{g}$ in the uncontaminated soil (Table. 3). Okoh (2006) demonstrated the presence of $\mathrm{C} 5-\mathrm{C} 10$ homologues in the petroleum fraction shown to be inhibitory to the majority of hydrocarbon degraders as solvents; these tend to disrupt lipid membrane structures of microorganisms. The lower microbial population in the contaminated soil could be as a result of the effect of the kerosene which could lead to impairment of gaseous exchange and retention of soil carbon dioxide (Ujowundu, 2011). These conditions in the present study might have resulted in increased acidity and decreased porosity of the contaminated soil.

Table 3: Total Fungal Colony Count in kerosene contaminated and uncontaminated garden soils

\begin{tabular}{|l|l|}
\hline Fungal population(Colony Forming Unit) \\
\hline Type of Soil & CFU/gm \\
\hline Garden (Uncontaminated) & $5.4 \times 10^{6}$ \\
\hline Kerosene (Contaminated) & $2.7 \times 10^{6}$ \\
\hline
\end{tabular}

Based on morphological and molecular(18S rRNA ) identification, ten native fungal species belonging to a total of five genera include Aspergillus (A. terreus, A. versicolor, $A$. niger); Fusarium oxysporum; Penicillium janthinellum, from the uncontaminated garden soil , whereas the contaminated soil included Candida tropicalis, Aspergillus (A. terreus, A. versicolor , A. niger); Cladosporium bruhnei, and Fusarium oxysporum(Table- 4) and showed 99 to $100 \%$ similarity with the NCBI fungal sequences through BLAST analysis. The loss in the fungal population in the kerosene contaminated soil could be as a result of the high concentration of the petroleum hydrocarbons especially the PAHs which are highly toxic to microbial cell membranes, Khan et al. (2013) showed similar findings while studying the impact of refined gasoline on the fungal population as a result of aged exposure. 
Table 4: Fungal taxa isolated from refined kerosene contaminated and uncontaminated garden soils, identified by length of 18S rRNA sequences by BLAST analysis

\begin{tabular}{|c|c|c|c|c|c|c|c|c|c|}
\hline \multirow[t]{2}{*}{$\begin{array}{c}\text { Soi } \\
1\end{array}$} & \multirow[t]{2}{*}{$\begin{array}{l}\text { Sequenc } \\
\text { e ID }\end{array}$} & \multirow[t]{2}{*}{$\begin{array}{l}\text { Lengt } \\
\mathrm{h}\end{array}$} & \multirow[t]{2}{*}{ TOP BLAST } & \multirow{2}{*}{$\begin{array}{l}\% \\
\text { Similari } \\
\text { ty }\end{array}$} & \multirow[t]{2}{*}{ Class } & \multirow[t]{2}{*}{ Order } & \multirow[t]{2}{*}{ Family } & \multicolumn{2}{|c|}{$\begin{array}{l}\text { NCBI GenBank } \\
\text { accessions numbers. }\end{array}$} \\
\hline & & & & & & & & Forward & Reverse \\
\hline \multirow{5}{*}{$\begin{array}{l}\mathrm{G} \\
\mathrm{A} \\
\mathrm{R} \\
\mathrm{D} \\
\mathrm{E} \\
\mathrm{N}\end{array}$} & SGX8 & 2713 & $\begin{array}{l}\text { Penicilliumja } \\
\text { nthinellum }\end{array}$ & $99 \%$ & Eurotiomycetes & Eurotiales; & $\begin{array}{l}\text { Trichocomace } \\
\text { ae }\end{array}$ & KC545846 & KC545847 \\
\hline & PGX9 & 1687 & $\begin{array}{l}\text { Aspergillusni } \\
\text { ger strain } \\
\text { HKS11 }\end{array}$ & $99 \%$ & Eurotiomycetes & Eurotiales & $\begin{array}{l}\text { Trichocomace } \\
\text { ae }\end{array}$ & KC545848 & KC545849 \\
\hline & SGX9 & 1714 & $\begin{array}{l}\text { Fusariumoxys } \\
\text { porum }\end{array}$ & $100 \%$ & $\begin{array}{l}\text { Sordariomycete } \\
\mathrm{s}\end{array}$ & Hypocreales & Nectriaceae & KC545850 & KC545851 \\
\hline & PGX10 & 1733 & $\begin{array}{l}\text { Aspergilluster } \\
\text { reus }\end{array}$ & $99 \%$ & Eurotiomycetes & Eurotiales & $\begin{array}{l}\text { Trichocomace } \\
\text { ae }\end{array}$ & KC545852 & KC545853 \\
\hline & PGX11 & 1733 & $\begin{array}{l}\text { Aspergillusve } \\
\text { rsicolor }\end{array}$ & $99 \%$ & Eurotiomycetes & Eurotiales & $\begin{array}{l}\text { Trichocomace } \\
\text { ae }\end{array}$ & KC545854 & KC545855 \\
\hline \multirow{6}{*}{$\begin{array}{l}\mathrm{K} \\
\mathrm{E} \\
\mathrm{R} \\
\mathrm{O} \\
\mathrm{S} \\
\mathrm{E} \\
\mathrm{N} \\
\mathrm{E}\end{array}$} & SKX1 & 1704 & $\begin{array}{l}\text { Candida } \\
\text { tropicalis }\end{array}$ & $99 \%$ & $\begin{array}{l}\text { Saccharomycet } \\
\text { es }\end{array}$ & $\begin{array}{l}\text { Saccharomycet } \\
\text { ales }\end{array}$ & $\begin{array}{l}\text { Saccharomyc } \\
\text { etaceae }\end{array}$ & KC545856 & KC545857 \\
\hline & SKX2 & 1687 & $\begin{array}{l}\text { Aspergillusni } \\
\text { ger strain } \\
\text { HKS } 11\end{array}$ & $100 \%$ & Eurotiomycetes & Eurotiales & $\begin{array}{l}\text { Trichocomace } \\
\text { ae }\end{array}$ & KC545858 & KC545859 \\
\hline & PKX3 & 1747 & $\begin{array}{l}\text { Cladosporium } \\
\text { bruhnei strain } \\
\text { USN } 11\end{array}$ & $99 \%$ & $\begin{array}{l}\text { Dothideomycet } \\
\text { es. }\end{array}$ & Capnodiales & $\begin{array}{l}\text { Davidiellacea } \\
\text { e. }\end{array}$ & KC545860 & KC545861 \\
\hline & PKX4 & 1729 & $\begin{array}{l}\text { Aspergilluster } \\
\text { reus }\end{array}$ & $100 \%$ & Eurotiomycetes & Eurotiales & $\begin{array}{l}\text { Trichocomace } \\
\text { ae }\end{array}$ & KC545862 & KC545863 \\
\hline & PKX5 & 1714 & $\begin{array}{l}\text { Fusariumoxys } \\
\text { porum isolate } \\
\text { K9 }\end{array}$ & $100 \%$ & $\begin{array}{l}\text { Sordariomycete } \\
\mathrm{s} ;\end{array}$ & Hypocreales & Nectriaceae & KC545864 & KC545865 \\
\hline & PKX6 & 1699 & $\begin{array}{l}\text { Aspergillusve } \\
\text { rsicolor strain } \\
\text { HDJZ-ZWM- } \\
16\end{array}$ & $100 \%$ & Eurotiomycetes & Eurotiales & $\begin{array}{l}\text { Trichocomace } \\
\text { ae }\end{array}$ & KC545866 & KC545867 \\
\hline
\end{tabular}

\section{Conclusion}

In this study, it was recorded that the aged refined kerosene soil is highly contaminated with petroleum hydrocarbons which affected soil physicochemical properties, fungal population and heavy metal enrichment which are important indicators for assessing soil quality, fertility and productivity. Besides, high organic carbon and total nitrogen, PAHs, heavy metal concentrations, low soil fertility index, $\mathrm{pH}$ and low moisture contents probably dwindle the growth of fungal strains in the contaminated soil. These adverse changes could affect nutrient cycle, impede nutrient uptake by plant roots and subsequently lead to reduction in crop yield. The findings of the study could be utilized for the standardization of bioremediation protocols. Growth and activity of microbes in such sites could be enhanced by increasing the moisture contents and incorporating surfactants in the soil which may further increase the bioavailability of petroleum hydrocarbons in the soil. 


\section{Acknowledgements}

One of the author's Ms. Shamiyan Rahat Khan is highly thankful to University Grants Commission (UGC) for financial support by receiving Maulan Azad Fellowship. Authors are also thankful to Sophisticated Instrumentation Centre for Advanced Research and Testing (SICART) for analysis of samples.

\section{References}

Akpoveta, O.V., Egharevba, F., Medjor, O.W., 2011.A pilot study on the biodegradation of hydrocarbon and its kinetics on kerosene simulated soil.International journal of environmental sciences 2, 54-67.

Amellal, N., Portal, J.M. and Berthelin, J., 2001. Effect of soil structure on bioavailability of polycyclic aromatic hydrocarbons within aggregates of a contaminated soil.Applied Geochemistry 16, 1611-19.

APHA: Standard methods for the examination of water and wastewater. 2005. 21st ed. Washington, DC: American Public Health Association.

Atlas, R.M., 1981. Microbial Degradation of Petroleum Hydrocarbons: an Environmental Perspective. Microbiological Reviews 45 (1), 180-209.

Awashthi, S.K., 2000. Central and State Rules as Amended for 1999: Prevention of Food Adulteration Act no 37 of 1954. $3^{\text {rd }}$ ed. Ashoka Law House, New Delhi.

Bahuguna, A., Lily, M.K., Mujal, A., Singh, R.N., Dangwal, K., 2011. A study on the physico -chemical analysis of automobile contaminated soil of Uttarakhand, India.International journal of Environmental Sciences 2 (2), 380-388.

Balks, M.R..Paetzold, R.P., Kimble, J.M., Aislabie, J. and Campbell, I.B., 2002. Effects of hydrocarbon spills on the temperature and moisture regimes of Cryosols in the Ross Sea region. Antarctic Science 14 (4), 319-326.

Black, C.A., 1965. Methods of Soil Analyses: Agronomy No. 9. American Society of Agronomy, Madison Wineosin

Blake, G.R., Harte, K.H., 1986. Methods of soil Analysis, pp. 363-375. America Society of Agronomy and Soil Science Society of America, Madison, Wisconsin, USA

Dejong, E., 1980. The Effect of a Crude Oil Spill on Cereals.Environmental Pollution22, 187-196.

Gee GW, Bauder JW. 1986. Methods of soil analysis, pp. 383-411. America Society of Agronomy and Soil Science Society of America, Madison, Wisconsin, USA

Gupta, S., Nayek, S., Saha, R.N. and Satpati, S., 2008. Assessment of heavy metal accumulation in macrophyte, agricultural soil and crop plants adjacent to discharge zone of sponge iron factory. Environmental Geology 55, 731-9.

Harrigan, W.F., McCance, M.E., 1990.Laboratory methods of food and diary microbiology. Academic Press, London.

Hawrot, M. and Nowak, A., 2006.Effects of Different Soil Treatments on Diesel Fuel Biodegradation.Polish Journal ofEnvironmental Studies 15(4),643-646.

Kisku, G.C., Barman, S.C. and Bhargava, S.K., 2000. Contamination of soil and plants with potentially toxic elements irrigated with mixed industrial effluent and its impact on the environment. Water, Air, and Soil Pollution 120, 121-37.

Khan, S. R., Kumar, J.I., Kumar, R.N., Patel, J.G., 2013. Physicochemical properties, heavy metal content and fungal characterization of an old gasoline- contaminated soil site in Anand, Gujarat, India. Environmental and Experimental Biology 11:137-143.

Lily, M.K., Bahuguna, A., Dangwal, K., Garg, V., 2009. Degradation of Benzo[a] Pyrene by a novel strain Bacillus subtilisBMT4i(MTCC 9447). Brazilian Journal of Microbiology 40(4), 884-892. 
Maiti, S.K., 2003 b. Handbook of methods in Environmentl studies: Vol:2 Air, Noise, Soil and overburden analysis. $1^{\text {st }}$ ed. Oxford book Company, Jaipur, Rajasthan, India

Malloch, D., 1997. Moulds Isolation, Cultivation and Identification. Department of Botany University of Toronto. Available from: http://www.botany.utoronto.ca/Researchlabs/MallochLab/Malloch/Cultivation.html

Minai-Tehrani, D. and Herfatmanesh, A., 2007. Biodegradation of aliphatic and Aromatic Fraction of Heavy crude Oil contaminated soil, A pilot Study. Bioremediation Journal11(20), $71-76$.

Nasrawi, H. A., 2012. Biodegradation of Crude Oil by Fungi Isolated from Gulf of Mexico. Journal of Bioremediation and Biodegradation 3(4), 1-6.

Nelson-Smith, A., 1973. Oil Pollution and Marine Ecology. Plenum Press, New York.

Nirmal Kumar, Hiren, S., Rita, N.K., Ira, B., 2008.Macrophytes in Phytoremediation of Heavy Metal Contaminated Water and Sediments in Parieyej Community Reserve, Gujarat, India. Turkish Journal of Fisheries and Aquatic Sciences 8, 193-200.

Nwachukwu, S.C.U., Ugoji, E.O., 1995. Impacts of crude petroleum spills on microbial communities of tropical soils. International Journal of Ecology and Environmental Science 21, 169-176.

Odu, C.T.I., 1977. Bulletin of the Science Association of Nigeria. Oil Pollution and the Environment, 282-289.

Okoh, A.I., 2006. Biodegradation alternative in the cleanup of petroleum hydrocarbon pollutants.Biotechnological andMolecular Biology Review1(2), 38-50.

Osuji, L.C., 2001. Total hydrocarbon content of soils, fifteen months after Eneka and Isiokpo oil Spills. Journal of Applied Sciences and Environmental Management 5(2), 35-38.

Osuji, L.C. and Nwoye, I., 2007. An appraisal of the impact of petroleum hydrocarbons on soil fertility: the Owaza experience. African Journal of Agricultural Research 2 (7), 318-324.

Reddy, C.A. and Mathew, Z., 2001. Fungi in Bioremediation, pp. 52-78. Cambridge University Press.

Sambrook, J., Fritch, E.F., Maniatis, T., 1989. Molecular cloning: A laboratory manual, $2^{\text {nd }}$ edn. Cold Spring Harbor Laboratory, Cold Spring Harbor, New York.

Sharma, R.K., Agrawal, M. and Marshall, F.M., 2006. Heavy metals contamination in vegetables grown in waste water irrigated areas of Varanasi, India. Bulletin of Environmental Contamination and Toxicology 77, 311-18.

Slavica, S.D., Slavica, B. and Brantner, B.A., 2003.Comparison of ultrasonic extraction and soxhlet extraction of polycyclic aromatic hydrocarbons from soil.Umweltanalytsches labor: Sachenplatz13, A-1200 Vienna, Austria.

Sztompka, E., 1999. Biodegradation of engine oil in soil.Acta Microbial Pollution 489, 185196.

Torstensson, L., Mikael, P. and Stenberg, B., 1998. Need of a Strategy for Evaluation of Arable Soil Quality. AMBIO 27 (1), 4-7.

Ujowundu, C.O., Kalu, F.N., Nwaoguikpe, R.N., Kalu, O.I., Ihejirika, C.E., Nwosunjoku, E.C., Okechukwu, R.I., 2011. Biochemical and Physical Characterization of Diesel Petroleum Contaminated Soil in Southeastern Nigeria. Research Journal of Chemical Sciences1(8), 57-62.

Verstrate, W., Vancooke, R., Berger, R. and Verlinde, A., 1975.Modelling of the breakdown and the motilization of hydrocarbon and the soil layers. In: Sharpley JN, Kaplan

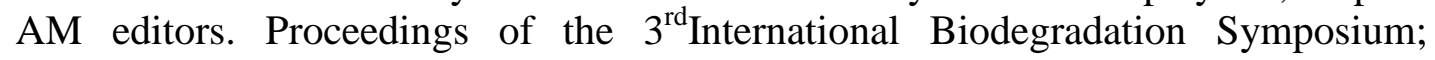
London: Applied Science Publisher, Ltd. 
Walkley, A. and I.A. Black., 1934. An examination of the Degtjareff method for determining organic carbon in soils: Effect of variations in digestion conditions and of inorganic soil constituents. Soil Science 63, 251-263.

WHO 'World Health Organization'. 1993. Evaluation of certain food additives and contaminants: 41st Report of the Joint FAO/WHO, Technical Report Series. Geneva: Expert Committee on Food Additives. 